water will have flowed under the bridge before the noble lord's money risks leaving his pocket, despite the improvements effected by the GLC.

The 'Thames, like the Chelmer, has not been without cyanide problems. Three drums each containing a hundredweight of cyanide were recently dropped into the water at a London dock, but the Thames so rapidly dispersed the chemical that it was undetectable two days later.

\section{Red Rain}

Motorists in south and central England who cleaned their cars during the last weekend of June regretted their diligence when they rose on Monday, July 1 , to find deposits of orange coloured dust over every exposed surface. The explanation was an early morning shower of rain, laden with dust swept up probably from somewhere in North Africa. The suspicion that this was an unusual event, even for a country which prides itself on the peculiarities of its climate, was soon verified by the Meteorological Office. Thumbing rapidly through the record books, it turned out that the last time a dust fall like this happened was in 1903. (There was, it is true, another dust storm in the $1930 \mathrm{~s}$, but not on the same scale.) The factors in the weather pattern for late June which led to this phenomenon are being investigated by the Meteorological Office. To help, there are weather satellite pictures of what seems to be the dust cloud moving north towards Britain.

On the same day as the widespread dust fall, Minehead and Dulverton in Somerset, and Burnley in Lancashire, were bombarded by hailstones the size of golf balls, according to a report in The Times. That this was no ordinary hailstorm is clear from the reports of smashed windows and dented cars, and damage done to an aircraft on the ground not far from Cardiff. The Meteorological Office is keeping an open mind on whether this is a coincidence or whether there was a causal relationship between the dust and the hail.

The dust itself is being examined by a number of research establishments. The Geochemical Division of the Institute of Geological Sciences, particularly quick off the mark, examined a sample which fell in North Wembley. Microscope and X-ray techniques show that the grains are chiefly quartz and feldspar, with smaller amounts of calcite and some mica. Its colour comes, it seems, from the presence of finely divided iron oxides, chiefly as a coating on the grains. Because there are no fragments of volcanic origin, the dust cannot have been carried into the upper atmosphere after a volcanic cruption, something which has been known to happen in the past. The presence of feldspar and calcite, minerals which break down rapidly in normal chemical weathering conditions, suggests that the dust comes from a desert region. A further clue is given by the microscopic appearance of the dust. Most of the grains are angular, although some of the coarser material is rounded. This is typical of the periphery of deserts; the sand from dunes in the central regions of descrts tends to be more rounded. The conclusion of the Institute of Geological Sciences is that the dust is a wind blown silt, known to geologists as locss, and may well have come from the margins of the Sahara desert.

The laboratories at Harwell, well equipped to deal with this kind of airborne fallout, have so far concentrated more on a study of the sizes of the dust particles.
Mr M. J. Heard and Mr R. D. Wiffen of the Health Physies and Medical Division sent to the Nature office their preliminary observations. They were particularly fortunate in collecting a sample of the rainfall on a clean glass slide, and so do not have to rely completely on more or less contaminated samples from motor cars claimed to have been clean before the shower. There seem to have been considerable local variations in the amount of the deposition, but the Harwell measurements, believed to represent the highest values, correspond to about $500 \mathrm{~kg} \mathrm{~km}^{-2}(1 \cdot 5$ tons per square mile). One interesting observation is that the quantity of material carried varied considerably from one raindrop to another; some of the smallest drops contained very large amounts of dust.

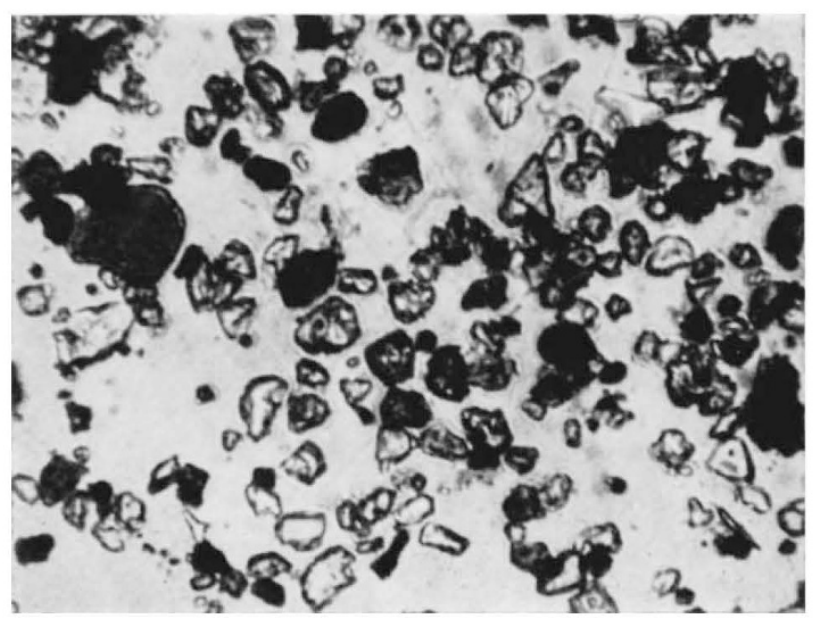

"Sahara dust"-magnified 100 times.

The deposit from a large drop was examined in detail to obtain the sizes of the dust particles. The size measurements fitted a log-normal distribution, yielding a geometric mean diameter of 0.47 microns and a mass median of 4.0 microns. There seems to have been some variation between individual droplets of the relative frequency of the larger particles. The largest particle measured was $48 \times 29$ microns. Optical microscopy showed particles with sharp outlines, well rounded at the larger sizes and progressively more angular as size decreased. An electron microscope revealed the considerable variety of particle and mineral types present.

\section{What they Earn}

Executives in British companies are paid less than their opposite numbers in Europe and the United States. Seientists who work in research and development scem to do worse than executives who concentrate on marketing, finance or production; only the luckless personnel officers are worse off. These results have emerged from a survey of executive salaries produced by United States consultants Towers, Perrin Forster and Crosby, recently published in Business Week.

Despite the increasing mobility of executives in Europe, and the penetration of American companies, both of which might be expected to create greater uniformity, there are still substantial differences between European countries. In Italy, for example, 


$\begin{array}{ll}\text { Salaries in Research and Development } \\ \text { Belgium } & £ 5,400-£ 7,5 \jmath 0 \\ \text { Britain } & £ 4,5 \jmath 0-£ 7,500 \\ \text { France } & £ 5,800-£ 8,300 \\ \text { Germany } & £ 5,000-£ 7,000 \\ \text { Italy } & £ 6,250-£ 10,400 \\ \text { Netherlands } & £ 5,400-£ 7,500 \\ \text { United States } & £ 7,500-£ 11,250\end{array}$

the scientist seems highly valued, and Italian salaries in general are more generous than the rest of Europe. In France, the marketing man docs best. It is perhaps surprising that each of the countries examined shows a similar trend, with marketing men at one end of the salary scale and personnel men at the other. In between are sandwiched executives in finance, production and research and development, in descending order. Salaries at the top end of the range in Europe are broadly comparable with those at the bottom end of the range in the United States.

The rate of growth of salaries in Europe has been rapid, according to the consultants, and one reason why British executives come out badly from the survey is because they have failed to increase their salaries as rapidly as their European counterparts. While salaries in France have gone up by 78 per cent, and in Belgium by 75 per cent in the past eight years, British executives now earn only 43 per cent more. West Germany, which boasted the highest executive salaries eight years ago, has shown only a 50 per cent growth.

\section{Making Booms Acceptable}

More research is needed on the physiological and psychological reactions to sonic booms, but it should be possible to build a supersonic jet that generates a boom of "acceptable characteristics". This is the general conclusion of a recent study on the human response to sonic boom carried out by a subcommittee of the Committee on SST-Sonic Boom under Professor Raymond A. Bauer of the Harvard School of Business Administration. The committee was set up by the National Academy of Sciences and the National Research Council at the request of the President in 1964.

Evidence from field studies indicates that there are no direct physiological effects-such as damage to hearing-from booms up to $100 \mathrm{lb}$./sq. ft, many times above any likely level, but that indirect physiological damage may occur from surprise at even "moderate" levels of noise. More studies of individual and community response must be made, however, whenever test conditions--such as airforce tests of supersonic jets over populated areas-are available. While the costs of such community studies-involving as they do a large number of interviewers and teams of competent researchers-may seem to be high, the report points out that the costs are slight compared with the large sums that would otherwise be spent later on SST redesign and development.

Those who are hoping for noiseless supersonic planes or restricted flights for SSTs are likely to be disappointed. The report's pragmatic approach is to look for the highest human tolerance level, in subgroups and in communities at large, and to leave engineers with the problem of keeping the boom within this level over heavily populated areas. The report points out that the level of individual discomfort is not necessarily the only criterion for defining an "intolerable" condition, for complaints are not always directly related to the level of physical discomfort. Studies must look into this phenomenon and try to determine which groups are more affected, or more actively protest, as well as considering such questions as whether people exposed to booms "become more or less tolerant over the course of time, whether booms in a noisy community are the 'straw that breaks the camel's back' or are merely one of many minor irritants".

The only consolation for many of us is Professor Bauer's point that the current commercial SST will need at least 100 miles after takeoff to reach a speed sufficient to generate a sonic boom, thereby avoiding the largest metropolitan areas on takeoff and landing.

\section{Tropical Techniques}

THE increasing number of enquiries from outside Britain is a sign that there is a world-wide and growing demand for the help of the Tropical Products Institute. According to the annual report of the institute, in 1967 there were 1,012 enquiries from 104 countries as well as international agencies, compared with 852 enquiries from 87 countries in 1966. Late in 1966 there was a change in emphasis of the research at the institute. It was decided to devote more resources to food science and technology, and 1967 was in effect the first year of the new policy. One of the most promising of the new projects is an attempt to increase the protein content of cassava or tapioca by fermentation. Cassava is a source of food starch and industrial starch and, in the normal processing of the erop, it is fermented and leached to remove toxic glycosides, but the resulting tapioca is deficient in protein. By using selected fungi and adding minerals, the protein content can be raised from $0 \cdot 1$ per cent in the original flour to 4 per cent and, if successful, further research could lead to conversion of tapioca into protein food on an industrial scale.

Apart from food research, the institute has followed up a chance observation made in Ethiopia which may lead to the development of new molluscicides active against the snails which carry bilharzia. People living at Adwa on the Assam River in Ethiopia use the fruit of the endod, which is rich in saponins, as natural soap. Dead snails and fish were noticed at the washing holes and laboratory tests showed that extracts of the endod fruit in tap water are potent molluscicides. At this stage the institute was asked for help in the identification and isolation of the active compounds. This work is still in progress, but the saponins have been identified as the molluscicides and there is every hope that the endod and a number of other tropical plants will become new sources on a commercial scale of molluscicides.

Another of the institute's projects sets out to make bricks from rice. The idea is that rice hulls, which are otherwise hard to dispose of, are available in large quantities and contain very few cement "poisons", might be used to replace gravel to produce lightweight concrete. Experiments have produced a way of making rice hull bricks strong enough to build one and two story houses. The institute is now starting to design simple presses and collapsible moulds for the large scale production of the bricks on building sites. 